\title{
A Literature Survey on Market-Based Measures for the Decarbonization of Shipping
}

\author{
Sotiria Lagouvardou *, Harilaos N. Psaraftis $(\mathbb{D}$ and Thalis Zis $(\mathbb{B}$ \\ Department of Technology, Management, and Economics, Technical University of Denmark, 2800 Kgs. Lyngby, \\ Denmark; hnpsar@dtu.dk (H.N.P.); tzis@dtu.dk (T.Z.) \\ * Correspondence: sotla@dtu.dk
}

Received: 11 April 2020; Accepted: 8 May 2020; Published: 12 May 2020

check for updates

\begin{abstract}
This paper aims to conduct an updated literature survey on the Market-Based Measures (MBMs) currently being proposed by various member states and organizations at the International Maritime Organization (IMO) or by the scientific and grey literature as a cost-effective solution to reduce greenhouse gas (GHG) emissions from ships. The paper collects, summarizes, and categorizes the different proposals to provide a clear understanding of the existing discussions on the field and also identifies the areas of prior investigation in order to prevent duplication and to avoid the future discussion at the IMO to start from scratch. Relevant European Union (EU) action on MBMs is also described. Furthermore, the study identifies inconsistencies, gaps in research, conflicting studies, or unanswered questions that form challenges for the implementation of any environmental policy at a global level for shipping. Finally, by providing foundational knowledge on the topic of MBMs for shipping and by exploring inadequately investigated areas, the study addresses concrete research questions that can be investigated and resolved by the scientific and shipping community.
\end{abstract}

Keywords: Market-Based Measures; greenhouse gas emissions; International Maritime Organization; shipping; EU Green Deal

\section{Introduction and Background}

\subsection{MBMs in Relation to Climate Policies}

Climate policies aim to reduce greenhouse gas (GHG) emissions in a cost-effective way. Traditionally, there are two main alternative approaches to assist in this goal: the "command and control" and the Market-Based Measures (MBMs) approach [1].

In a command and control scenario, a designated authority formulates a direct regulation by setting benchmarks for restricting the factors that lead to GHG emissions (for instance, speed, power, or fuel consumption limits). In a global environment like shipping, where there is a high degree of variability in vessel building specifications and operating practices, the identification of benchmarks is very challenging [2]. The enforcement requires a significant amount of resources as well as detailed ship specific knowledge to set up, operate, and review in order to avoid distortions of competition among the different sectors (bulk, container, cruise, etc.). A command and control approach restricts investments in technology as it gives little or no incentive for firms to innovate [3] and can penalize green operators; for instance, by forcing two vessels to sail at the same speed when one uses more energy-efficient propulsion technology.

Measures characterized as "goal-based" may be considered to be a subset of the command and control class, as they only prescribe an emissions reduction target, without prescribing the means for reaching the target, leaving this to the discretion of the ship-owner. Some of the short-term measures currently under discussion at the IMO fall under this category. 
On the other hand, Market-Based Measures (MBMs) or Market-Based Instruments (as was their original name) are more flexible measures that use prices or other economic variables to provide monetary incentives for polluters to reduce emissions. MBMs apply the "polluter pays principle"-i.e., they internalize the negative external environmental cost of the emissions by forcing the polluter to compensate for that cost. Examples are environmental taxes, the provision of subsidies, various offsetting mechanisms, and Emission Trading Systems (ETS). In other words, by imposing indirect market-based regulations, MBMs let the stakeholders decide the way to respond and minimize the cost of their emissions. Their response can range from logistics-based measures such as speed reduction to technical measures such as investing in more energy-efficient technologies or alternative fuels.

The purpose of this paper is to conduct an updated literature survey on the MBMs proposed by various member states and organizations at the International Maritime Organization (IMO), or by the scientific and grey literature as cost-effective solutions to reduce greenhouse gas (GHG) emissions from ships. Relevant European Union (EU) action is also described. Due to essential decisions on how to decarbonize international shipping, we believe that such a survey serves a definite need.

To structure a comprehensive literature review, we divided the available material into three classes: (a) relevant submissions and other material on MBMs at the IMO and the EU level, (b) scientific literature and (c) grey literature. All the IMO submissions were mapped by the platform of "IMO Docs" using keywords such as "Market-Based Measures", "MBMs" and "reduction of GHG emissions from ships". We thus gathered all relevant documents affiliated with MBMs since their first appearance in 2000. For the EU, we looked at relevant legislation and other documents. For the scientific literature, we used the online library platform "DTU Findit" which is the Open Science oriented Library Services Platform (LSP) of DTU and gives access to various accredited data providers (Scopus, Web of Science, etc.). The keywords used for DTU Findit contained words such as "Market-Based Measures for shipping", "emissions trading system for shipping", "bunker levy for shipping", etc. Doing so, we came up with some 220 results, of which many were not relevant as they would only mention MBMs as an available measure but would focus on operational or technical measures for decarbonizing shipping. Finally, we included published reports from the non-scientific community, which includes various institutions that play a key role in the decision-making process in the shipping sector. The reports included in this review were chosen based on their relevance with the MBM policy formulation and were recently published.

The rest of this paper is structured as follows. The rest of Section 1 looks at the history of regulatory developments and the current GHG emissions reduction potentials. Section 2 consists of a summary table that briefly describes all the proposals submitted to the IMO from various member states and other organizations and those advanced by the EU. Section 3 presents the key findings of the scientific literature on MBMs. Section 4 includes the results of various published reports on MBMs in the grey literature. Finally, Section 5 presents the conclusions of the paper, identifies various gaps in the literature and scenarios that need to be further studied as future implications of MBMs.

\subsection{History of Regulatory Developments}

It seems that the idea of the "internalization of costs" to achieve sustainable financing for the prevention, clean up, or compensation of costs caused by "polluters" was first raised internally at the IMO in 1995 [4], however, no follow-up action was taken. The first assessment on the potential use of MBMs for obtaining reductions of GHG emissions for shipping was conducted in the 1st GHG Study in 2000 [5]. However, it was not until 2010 when the first discussions on MBMs took place within the IMO community. At the 60th session of IMO's Marine Environment Protection Committee (MEPC 60), 11 MBMs were proposed by several member states of the IMO and IMO observer organizations. Following these submissions, an expert group was tasked to conduct a comprehensive assessment of the proposals [6]. Despite their extensive research, the group's report came up with no apparent result on which measure addresses the GHG emission reduction challenge more effectively. Finally, despite the debate that followed at the IMO, the MBM discussion was suspended in 2013. 
Meanwhile, in 2011 (MEPC 62), the Energy Efficiency Design Index (EEDI) was made mandatory for new ships, and the Ship Energy Efficiency Management Plan (SEEMP) was adopted for all ships of 400 GRT and above. For the shipping industry, this was the first legally binding climate change treaty adopted since the Kyoto Protocol and came into force as of 1 January 2013.

Additionally, in 2013, the EU started the discussion for Monitoring, Reporting, and Verification (MRV) of $\mathrm{CO}_{2}$ emissions for ships of over $5000 \mathrm{GT}$ calling at EU ports. Two years later, in 2015, the MRV became mandatory, and the reporting period was set for the beginning of 2018. Following a similar path, but on a global scale, the IMO in 2016 introduced the Data Collection System (IMO DCS) for vessels of 5000 GT and above trading internationally, setting as the first reporting date 1 January 2019.

At MEPC 70 (2016), a road map for the development of a comprehensive IMO strategy on reducing GHGs from ships was approved, leading to the adoption of the so-called Initial IMO Strategy at MEPC 72 in April 2018 [7]. The strategy represents the response of the shipping community to the global goals set out in the Paris Agreement (December 2015) for maintaining a global average temperature increase to 'well below' 2 degrees Celsius above pre-industrial levels and striving for 1.5 degrees. More specifically, the strategy aims to reduce total annual GHGs from shipping by at least $50 \%$ by 2050 compared with 2008 levels, while, concurrently, pursuing efforts towards phasing them out entirely. The strategy also sets to decrease the sector's average carbon intensity by at least $40 \%$ until 2030 , and $70 \%$ by 2050 and introduces the vision, the level of ambition and the guiding principles of the IMO along with a list of candidate measures that can achieve those targets.

The proposed candidate measures include short-term, mid-term, and long-term plans that would lead to the adoption of a revised and possibly stricter strategy by 2023. The short-term or logistics-based measures focus on improving the operational energy efficiency of existing ships and include the use of speed optimization, weather routing, and fleet management techniques. The medium-term possibly includes MBMs that can implement the "polluter-pays" principle and therefore, internalize the external cost of the GHG emissions. Long-term or technological measures mostly include the use of low carbon or alternative fuels like biofuels, ammonia, and hydrogen, along with energy recuperation devices (e.g., exhaust heat recovery systems) and wind-assisted propulsion.

It should be noted here that MBMs can induce both short-term, logistics-based actions such as speed reduction, and long-term actions such as investment in energy saving technologies or alternative fuels which would otherwise be non-viable. However, the use of the phrase "possibly include MBMs" by the IMO means that the fate of MBMs at the IMO is currently unclear. In order to assess the effectiveness of MBMs, any discussion at the IMO should distinguish the prime target for the implementation. By enforcing the "polluter pays" principle, it proposes that restrictive measures on the damage on environment will be reduced but continued. MBMs can initially induce the appropriate changes towards emissions reduction but a scenario of complete decarbonization can be foreseen only in the case that MBMs are properly designed to boost towards the transition to new fuels and propulsion systems. Due to their market nature, MBMs can also introduce a sense of fairness in the industry by rewarding green operators, however, in case of false standardization of the efficiency target, the final goal might be neglected. In any case, complete decarbonization of shipping needs pluralistic solutions and a properly designed and easily enforced MBM that can facilitate the changes towards that direction.

The European Parliament (EP) in 2017 voted that shipping will be included in the EU ETS by 2023, in case IMO has not introduced global legislation by 2021. The decision faced various objections from the industry's stakeholders, such as European Community Ship-owners Associations (ECSA), International Chamber of Shipping (ICS), and various national ship-owner corporations. It was subsequently decided to align the EU with the IMO process; however, the European Commission (EC) monitored the IMO process very carefully and refused to take the ETS option off the table.

In December 2019, the new EC president, Ursula von der Leyen, during the COP-25 climate conference in Madrid, expressed her willingness to make Europe the first climate-neutral continent by 
2050 by introducing the "European Green Deal." Doing so would involve, among other things, include shipping within the EU ETS [8].

Specifically, the EP's rapporteur, Jutta Paulus, proposed to align the EU MRV with the IMO DCS for reducing the administrative burden of ships reporting to both regulations [9]. Although the proposal includes substantial amendments to the MRV parameters in order to align it with IMO DCS, the new additions on the proposal were more alarming as they include stricter emission reductions targets and a different enforcement date for including shipping in the EU ETS (January 2021 despite the initial agreement of 2023). The new additions will force vessels to reduce their carbon intensity by $40 \%$ by 2030 compared with 2018 levels. Additionally, until December 2020, agreements on the total quantity of allowances, the method of their allocations through auctioning, and various special provisions for the EU members that will administer the system will be made. Finally, the proposal suggests that at least $30 \%$ of the revenues generated from the auctioning will finance a maritime decarbonization fund for the period 2021-2030. The fund aims to "improve the energy efficiency of ships and support investment in innovative technologies and infrastructure to decarbonize maritime transport, including in short sea shipping and ports, and the deployment of sustainable alternative fuels and zero-emission propulsion technologies." The proposal is not likely to become the vehicle for the ETS as it requires substantial amendments to the scope of MRV not being related to the pricing of the recorded emissions.

The Environment Committee of the EP (ENVI Committee) has to agree prior to the proposal being debated by the plenary of the Parliament. The EU Council that represents the EU Governments will proceed with its suggestions on the proposal once that text is approved. The suggestions will be followed by more parliamentary and Council deliberations, culminating in a compromise agreement. With both the EC and the EP strongly endorsing the inclusion of shipping in the ETS, the shipping industry's best opportunity to thwart such proposals will be lobbying national governments to block or weaken the undesirable sections of the proposal.

More on the EU ETS is presented in the analysis of Section 2.3.

\subsection{Current Measures of Emissions Reduction Potentials}

According to the 3rd IMO GHG Study [10] in 2012, international shipping emitted 796 million tons of $\mathrm{CO}_{2}$, accounting for $2.2 \%$ of the total global anthropogenic $\mathrm{CO}_{2}$ emissions that year. Besides, the study concludes that emissions from international shipping could grow between $50 \%$ and $250 \%$ by 2050 if no action is taken, mainly due to the growth of the world maritime trade.

The importance of reaching the sustainability targets in the shipping sector was investigated by Wang et al. [11]. The study investigates and prioritizes the key role of 17 Sustainable Development Goals (SDGs), adopted by the UN in 2015, addressing crucial issues like poverty, hunger and health. For the maritime sector, after the analysis, the paper concludes that the development of green technologies and transport infrastructure is a core responsibility of the sector and among the top priorities.

With regards to the projected growth in world trade to $39 \%$ by 2050 by DNV GL [12], technical and operational measures are not sufficient to reduce the amount of GHG emissions. It is highlighted in that report that the total $\mathrm{CO}_{2}$ emission level can be reduced by only $27 \%$ in mid-century, as compared to 2008, even if the energy efficiency of ships and operations is improved dramatically. Therefore, and according to that report, the 2050 ambitions are not achievable with current policies unless carbon neutral or low carbon fuels become competitive with current fossil fuel prices.

Many researchers who investigated the reduction abatement potentials of the current operational measures also adopt the same rationale. Buhaug et al. [13], Eide et al. [14], Faber et al. [15], Gilbert et al. [16] and Lindstad et al. [17], among others, estimated how much it is possible to reduce GHG emissions up to 2050. Some of the high GHG reduction scenarios assume the use of biofuels.

As EEDI and SEEMP only entered into force on 1 January 2013, it may take a long time for the international community to identify the precise effectiveness of these measures in terms of an absolute reduction of GHG emissions. Shi et al. [18] revealed that GHG emissions from international shipping 
are projected to increase even with the mandatory implementation of the EEDI and the SEEMP because of the expected future growth in world trade. Smith et al. [19] estimated that the GHG reduction of an EEDI versus a non-EEDI scenario by 2050 would be no more than $3 \%$. Furthermore, the EEDI will only cover the emissions from new vessels, which indicates that even after 12-15 years after enforcement, only half of the fleet will comply, and the long-term emission reduction results are questionable. Finally, a ship with low EEDI is not always a ship with low $\mathrm{CO}_{2}$ emissions. An underpowered ship in adverse weather conditions will emit more $\mathrm{CO}_{2}$ than a ship equipped with a large scale engine while trying to maintain a constant speed [20].

Nevertheless, neither the IMO DCS nor the EU MRV systems can directly lower $\mathrm{CO}_{2}$ emissions by themselves, despite the increase of fuel consumption awareness [21]. According to the analytical and preparatory work done for the EU MRV [22], the EU MRV could lead to annual reductions in fuel consumption and emissions of around $2 \%$ due to an increase in transparency and awareness. However, based on the same report, the $\mathrm{CO}_{2}$ emissions related to EEA maritime transport activities are expected to grow and reach 271 million tons of $\mathrm{CO}_{2}$ in 2050 ( $+39 \%$ compared to 2005).

Operation-wise, speed reduction is probably the easiest operational measure to consider for achieving reductions on fuel consumption $[15,23]$. However, slow steaming is already implemented due to the depressed market conditions and the overcapacity of the world's fleet after 2008. Therefore, Christodoulou et al. [24] claim that slow steaming will not reduce emissions significantly unless the market improves, and the average speeds increase.

The solution to implementing a speed limit has been advocated by France and several non-governmental organizations (NGOs) such as the Clean Shipping Coalition (CSC). However, at MEPC 74, the measure was rejected as it discourages innovation and does not ensure GHG emissions reductions. Furthermore, a speed limit does not allow low carbon fuels or energy efficiency solutions to develop and penalize the green operators that can achieve higher operational speeds with reduced fuel consumption.

Cariou studied the $\mathrm{CO}_{2}$ emission reduction potential of slow steaming in combination with an MBM that would stabilize bunker prices at a high level [25]. Since MBMs are based on the assumption that higher fuel prices will incite operators to reduce speeds, studies such as that of Corbett et al. [26] investigated how decisions on speed are influenced by fuel prices. However, data presenting by Lindstad et al. [27] indicate that the correlation between speed and fuel price is complicated and that their impacts have been overestimated. Such an argument is based on Pareto solutions-where cost and emissions are optimized-and concludes that decisions on speed are also the general market conditions, the ship-owner decisions, and customer preferences.

Last but not least, the review of Shi et al. [28] focused on the investigation of the research that had been conducted so far on sustainable shipping. The results indicate that the main focus in green shipping is on air pollution and, more specifically, on the classification of measures to reach those goals such as the technical, operational, and market-based measures along with recycling and reusing. The study also concludes that future work should focus more on green technology, and policies that are needed to attain the sustainability goals.

\section{MBMs at the IMO and the EU}

\subsection{The Initial Submissions at the IMO (2010-2013)}

In 2010, eleven MBM proposals were submitted to MEPC 60, and the discussion on MBMs at the IMO continued until 2013. Table 1 summarizes the submissions and briefly describes each MBM proposal and the method to achieve reductions on GHG emissions.

For the discussion of these 11 proposals, the IMO Secretary-General appointed an expert group to develop a comprehensive assessment of the submitted documents. The report [6] performed an evaluation of the various proposals according to specified criteria, but came up with no preference or recommendation on which measure to implement for achieving GHG emission reductions. A qualitative comparison was performed by Psaraftis [29]. 
Table 1. Initial Market Based Measures (MBM) Submissions at the International Maritime Organization (IMO) in 2010. See [5] and [27] for more details.

\begin{tabular}{|c|c|c|c|c|c|}
\hline \multirow{2}{*}{ Type of MBM } & \multirow{2}{*}{ MBM Proposal } & \multirow{2}{*}{ Proponents } & \multirow{2}{*}{ Brief Description } & \multicolumn{2}{|c|}{ Mechanism for Reduction } \\
\hline & & & & In Sector & Out of Sector \\
\hline Levy on bunker fuels & $\begin{array}{l}\text { The International Fund for } \\
\text { Greenhouse Gas (GHG) } \\
\text { emissions from ships (GHG } \\
\text { Fund) [30] }\end{array}$ & $\begin{array}{l}\text { Cyprus, Denmark, the } \\
\text { Marshall Islands, Nigeria, } \\
\text { Republic of Korea and the } \\
\text { International Parcel } \\
\text { Tankers Association } \\
\text { (IPTA) }\end{array}$ & $\begin{array}{l}\text { United Nations Framework Convention on } \\
\text { Climate Change (UNFCCC) and IMO set a } \\
\text { global emission reduction target for the } \\
\text { shipping sector. Emissions above the } \\
\text { target are offset by purchasing approved } \\
\text { emission reductions credits. All ships } \\
\text { contribute to the Fund when they purchase } \\
\text { fuel. The fund adjusts the size of the } \\
\text { contribution in order to ensure that this } \\
\text { can buy the offsets needed; for the sector to } \\
\text { meet the emission target. }\end{array}$ & $\begin{array}{l}\text { It sets a global reduction } \\
\text { target and increases the } \\
\text { cost of bunker fuels. }\end{array}$ & $\begin{array}{l}\text { Purchase of project offset } \\
\text { credits through the } \\
\text { revenues. }\end{array}$ \\
\hline \multirow{4}{*}{$\begin{array}{c}\text { Emissions Trading System } \\
\text { (ETS) }\end{array}$} & $\begin{array}{c}\text { The Global Emission Trading } \\
\text { System for international } \\
\text { shipping [31] }\end{array}$ & Norway & $\begin{array}{l}\text { A cap-and-trade system where credits are } \\
\text { traded in-sector or out-of-sector. The } \\
\text { system uses an auctioning system while it } \\
\text { releases into the market emissions } \\
\text { allowances (corresponding to the cap) } \\
\text { yearly. }\end{array}$ & $\begin{array}{l}\text { It sets a global cap and a } \\
\text { price on emissions from } \\
\text { shipping-purchase of } \\
\text { in-sector offset credits. }\end{array}$ & $\begin{array}{c}\text { Purchase of project offset } \\
\text { credits. }\end{array}$ \\
\hline & $\begin{array}{c}\text { Global Emissions Trading } \\
\text { System for international } \\
\text { shipping [32] }\end{array}$ & United Kingdom & $\begin{array}{l}\text { Same concept with Norway's proposal but } \\
\text { a different method for allocating emissions } \\
\text { allowances and a different approach to } \\
\text { determining the cap. }\end{array}$ & $\begin{array}{l}\text { It sets a global cap and a } \\
\text { price on emissions from } \\
\text { shipping-purchase of } \\
\text { in-sector offset credits. }\end{array}$ & $\begin{array}{c}\text { Purchase of project offset } \\
\text { credits. }\end{array}$ \\
\hline & $\begin{array}{c}\text { Further elements for the } \\
\text { development of an Emissions } \\
\text { Trading System for } \\
\text { International Shipping [33] }\end{array}$ & France & $\begin{array}{l}\text { The same concept with Norway's proposal } \\
\text { but adds some detail on auctioning design. }\end{array}$ & $\begin{array}{l}\text { It sets a global cap and a } \\
\text { price on emissions from } \\
\text { shipping-purchase of } \\
\text { in-sector offset credits. }\end{array}$ & $\begin{array}{l}\text { Purchase of project offset } \\
\text { credits. }\end{array}$ \\
\hline & $\begin{array}{c}\text { Design and implementation } \\
\text { of a worldwide Maritime } \\
\text { Emission Trading Scheme } \\
\text { (METS) [34] }\end{array}$ & Germany & $\begin{array}{c}\text { In favor of an ETS, Germany provided a } \\
\text { scientific study that examines global ETS } \\
\text { and concludes that it is an effective, } \\
\text { cost-efficient, and applicable instrument to } \\
\text { enforce. }\end{array}$ & $\begin{array}{l}\text { It sets a global cap and a } \\
\text { price on emissions from } \\
\text { shipping-purchase of } \\
\text { in-sector offset credits. }\end{array}$ & $\begin{array}{l}\text { Purchase of project offset } \\
\text { credits. }\end{array}$ \\
\hline
\end{tabular}


Table 1. Cont.

\begin{tabular}{|c|c|c|c|c|c|}
\hline \multirow{2}{*}{ Type of MBM } & \multirow{2}{*}{ MBM Proposal } & \multirow{2}{*}{ Proponents } & \multirow{2}{*}{ Brief Description } & \multicolumn{2}{|c|}{ Mechanism for Reduction } \\
\hline & & & & In Sector & Out of Sector \\
\hline \multirow{3}{*}{$\begin{array}{l}\text { Hybrid with Energy } \\
\text { Efficiency Design Index } \\
\text { (EEDI) as a benchmark }\end{array}$} & $\begin{array}{l}\text { The Leveraged Incentive } \\
\text { Scheme (LIS) to improve the } \\
\text { energy efficiency of ships } \\
\text { based on the International } \\
\text { GHG Fund [35] }\end{array}$ & Japan & $\begin{array}{l}\text { The same concept with the GHG Fund but } \\
\text { vessels labeled as "good performance } \\
\text { ships" (i.e., they meet predetermined EEDI } \\
\text { targets) will be refunded their contribution } \\
\text { to the GHG Fund. }\end{array}$ & $\begin{array}{l}\text { Refund policy and EEDI } \\
\text { inclusion incentivize } \\
\text { investments in } \\
\text { zero-carbon technology. }\end{array}$ & $\begin{array}{l}\text { Purchase of project offse } \\
\text { credits through the fund }\end{array}$ \\
\hline & $\begin{array}{l}\text { The United States proposal to } \\
\text { reduce GHG emissions from } \\
\text { international shipping, Ship } \\
\text { Efficiency, and Credit Trading } \\
\text { (SECT) [36] }\end{array}$ & United States & $\begin{array}{l}\text { Ships have to meet mandatory efficiency } \\
\text { standards that will become stricter over } \\
\text { time. SECT establishes an efficiency-credit } \\
\text { trading program that trading is based on } \\
\text { vessels' EEDI. }\end{array}$ & $\begin{array}{l}\text { Trading based on EEDI } \\
\text { incentivizes for } \\
\text { investments in } \\
\text { energy-efficient } \\
\text { technologies. }\end{array}$ & N/A \\
\hline & $\begin{array}{l}\text { Vessel Efficiency System } \\
\text { (VES) [37] }\end{array}$ & World Shipping Council & $\begin{array}{l}\text { Establishment of mandatory efficiency } \\
\text { standards for both new and existing ships. } \\
\text { New builds must meet the standards to } \\
\text { operate, whereas existing ships are forced } \\
\text { to improve their efficiency by utilizing the } \\
\text { respective technology. Ships that do not } \\
\text { meet the standards will be subject to a levy } \\
\text { based on how far the measured EEDI falls } \\
\text { short from the standard. }\end{array}$ & $\begin{array}{l}\text { Mandatory efficiency } \\
\text { standards. EEDI } \\
\text { incentivizes for } \\
\text { investments in } \\
\text { zero-carbon technology. }\end{array}$ & $\begin{array}{l}\text { Purchase of project offse } \\
\text { credits through the } \\
\text { revenues. }\end{array}$ \\
\hline \multirow{3}{*}{ Other } & $\begin{array}{l}\text { Market-based instruments: } \\
\text { a penalty on trade and } \\
\text { development [38] }\end{array}$ & Bahamas & A “do-nothing" MBM. & N/A & N/A \\
\hline & $\begin{array}{l}\text { Achieving a reduction in } \\
\text { GHG emissions from ships } \\
\text { through Port State } \\
\text { arrangements utilizing the } \\
\text { ship traffic, energy, and } \\
\text { environment model, Port } \\
\text { State Levy (PSL) [39] }\end{array}$ & Jamaica & $\begin{array}{l}\text { A uniform emissions charge will be agreed } \\
\text { upon for any vessel calling at their ports. } \\
\text { Vessels will pay a levy based on the fuel } \\
\text { consumption of their voyage to the } \\
\text { respective port. Ships with exceeding } \\
\text { energy efficiency targets will be leveraged. }\end{array}$ & $\begin{array}{l}\text { Sets efficiency standards } \\
\text { and incentivizes for } \\
\text { investments in } \\
\text { zero-carbon technology. }\end{array}$ & $\begin{array}{l}\text { Purchase of project offse } \\
\text { credits through the } \\
\text { revenues. }\end{array}$ \\
\hline & $\begin{array}{l}\text { A rebate mechanism (RM) for } \\
\text { a market-based instrument } \\
\text { for international shipping } \\
\text { proposal by the International } \\
\text { Union for Conservation of } \\
\text { Nature (IUCN) [40] }\end{array}$ & IUCN & $\begin{array}{l}\text { An add-on to any MBM proposal that aims } \\
\text { to compensate developing countries for the } \\
\text { financial impacts of MBMs based on their } \\
\text { share of global imports and costs. }\end{array}$ & $\begin{array}{l}\text { The approach based on } \\
\text { the chosen MBM. }\end{array}$ & $\begin{array}{l}\text { The approach based on } \\
\text { the chosen MBM. }\end{array}$ \\
\hline
\end{tabular}


Subsequently, the following member states amended their proposals, as stated below:

1. The Bahamas submitted an evolution of their original "do-nothing" proposal [41] and finally withdrew it completely.

2. The proposals of Japan and the WSC (LIS and VES) were merged into one that was relabeled the Efficiency Incentive Scheme (EIS) [42]. Japan and the WSC recommended the establishment of specific efficiency standards for both new and existing ships in the world fleet based on the EEDI.

As stated earlier, the IMO discussion on MBMs was suspended in 2013, and the discussion was rechanneled towards the MRV/DCS discussion.

\subsection{Recent Submissions to the IMO}

There have also been some recent MBM submissions to the IMO. In 2018, France [43] expressed the belief that MBMs can create the appropriate economic context towards low/zero-carbon fuels and technologies. The French proposal consists of a progressively increasing carbon price based on the quantity of carbon a vessel emits. This action would benefit low and zero-carbon fuel users and boost technological advances in this direction. Ships that meet the specified standards are exempt from any fees, penalties, or costs other than those associated with the installation of energy-efficient technologies. Ships that do not meet the standards would be required to pay a fee on the consumed fuel based on the difference between the attained efficiency and the agreed standards. As such, the per-unit fee applied per ton of fuel is based on the relative efficiency of the vessel.

Additionally, in 2018, Antigua and Barbuda et al. [44] submitted a proposal urging for financial incentives, R\&D investment, and regulation in order to meet the levels of ambition in the Initial Strategy. They express their preference towards an easily implemented and transparent carbon tax or levy on bunker fuel. The level of the levy should be reviewed frequently and increased over time. Furthermore, the co-sponsors convey their belief that the generated revenues should compensate the impacts on Small Island Developing States (SIDS), and on Least Developed Countries (LDCs), and mitigate the effects of climate change by the most vulnerable.

In 2019, Norway [45] submitted a proposal urging the need of flexible compliance mechanisms for meeting the $\mathrm{CO}_{2}$ and GHG requirements. According to the submission, the introduction of alternative low/zero-carbon fuels is essential for meeting the 2050 ambitions even in low market growth scenarios, and it would be challenging for existing ships to meet the targets. The proposal suggests that those ships could compensate for their emissions by utilizing "fleet averages, annual accounting, out-of-sector fund or in-sector fund." Another compliance mechanism could be the contribution to a certified IMO GHG R\&D Fund. IMO would establish an equivalent $\mathrm{CO}_{2}$ reduction fee as a financial contribution to the Fund based on the price of $\mathrm{CO}_{2}$ in existing markets. Finally, the revenues of the Fund would be used to stimulate a transition towards low/zero-carbon fuels and technologies.

The most recent proposal to the IMO was submitted in 2020 by ICS and BIMCO et al. [46], and has not been named an MBM. The measure proposes the establishment of a mandatory contribution fund per ton of fuel oil purchased. Revenues are estimated at 5 billion USD, aiming to enhance R\&D towards low and zero-carbon fuel, and promote the development of commercially viable zero-carbon emission ships by the early 2030s. Based on the assumption that the yearly fuel oil consumption is approximately 250 million tons, the co-sponsors propose that the quantum of the R\&D contribution would be 2 USD per ton of marine fuel purchased, and the program will last over ten years.

\subsection{MBMs at the EU}

If the IMO discussion on MBMs is currently suspended with no clear sign when it will resume, the EU seems to be moving full speed on the MBM front. The EC's commitment to tackle climate change led to the communication of a European Green Deal which would "transform the EU into a fair and prosperous society, with a modern, resource-efficient and competitive economy where there are no net emissions of greenhouse gases in 2050 and where economic growth is decoupled from 
resource use" [8]. The recent amendment to the EU ETS Directive, through Directive (EU) 2018/410 of the European Parliament and the Council, emphasizes the need for the system to act on shipping emissions. Furthermore, the latest statements of the EP's maritime emissions rapporteur, Jutta Paulus, to include the sector in the EU ETS have been excessively persistent and increased in frequency, exerting pressure on the IMO to take action. The EU ETS was enforced in 2005 and so far includes more than 11,000 heavy energy-using installations (power stations and industrial plants) as well as aviation. However, including an international sector that operates globally, like shipping and aviation to a regional scheme, has proven challenging and maybe will induce countereffects to the trade inside the EU. Recent reports studying the effectiveness of the scheme conclude that total emissions from the participating sectors have declined, but emissions from aviation have increased since its inclusion in the scheme. This conclusion proves that regulating sectors trading internationally needs to be done on a global scale.

The justification for including shipping into the EU ETS came from an Impact Assessment (IA) conducted by the EC circa 2013 [47], in which the EC examined several GHG reduction options and concluded that ETS was the best one. Supporting documentation for the IA came in a detailed Technical Report (TR) commissioned by the EC and prepared by a consortium of partners according to Ricardo et al. in 2013 [48].

Both the IA and the TR are very comprehensive; however, neither contains information on the model that evaluated the various policies for reducing maritime GHG emissions. The model was based on the so-called TIMES energy model and was specifically developed for the IA. We were unable to access or find in the literature any specific information regarding the structure, methodology, or inputs and parameters of that model. We also note that even though the TR contained no recommendation on which of the GHG reduction measures was the best, the IA made its ETS choice based on the contents in the technical report.

The results of the analysis vary widely and depend on the examined aspect (effectiveness, efficiency, consistency). Even though this is not clearly stated in conclusions, the outcome of the analysis shows that the "closed ETS" solution is superior to all other options. A closed ETS means that it is exclusive to maritime GHG emissions, whereas an open ETS would allow trading of allowances to other energy sectors. However, there are no clear indications of how a closed ETS can be developed from scratch, and the potential inclusion of shipping in the EU ETS that would allow trading of allowances among sectors would not fall under the categorization of the optimal solution of a closed ETS.

From a legal point of view, there are concerns that a regional scheme that regulates all GHG emissions arising on voyages to and from the EU is not compatible with international law. According to Hermeling et al. [49], a comprehensive scheme would have extra-territorial effects in conflict with the flag-state principle (Article 92 UNCLOS) and disregard the prohibition to all states to subject any part of the high seas to its sovereignty (Article 89 of UNCLOS), and, as a consequence, would violate world trade law. However, according to the TR and the IA, only mandatory emissions reduction policies are not compatible with UNCLOS.

The case of a tax on fuels is also assessed in the TR. Regarding the design of the policy, it is stated that "The Compliance Entity would have the option to pay the additional tax charges without modifying their fuel consumption/emission levels, or to operate more efficiently in order to reduce the amount of tax they pay under the scheme." [48]. Our question is: How is this not the case for designing an ETS with the compliance entities simply offsetting the emissions by purchasing credits?

Furthermore, on the design details of a tax on bunker fuels, it is stated that "The fundamental property of a tax is that it provides cost certainty, not certainty of emission reductions. The tax would reduce emissions only to the extent that it encourages vessels to be operated in a more fuel-efficient manner, so overall emissions may not decline, i.e., if vessels opt to pay the additional charges without modifying their operations." [48]. If this is the case for a bunker levy, even worse may be the case with an ETS scenario, where the market price of carbon is low or unpredictable. 
So to the best of our knowledge, the major policy decision to include shipping in the EU ETS has been based on models that are non-transparent or not open to scrutiny, and also entails other issues that are unclear or unresolved. This, in our opinion, does not justify this decision and can lead to confusion and misguide the decision-making process.

\section{MBMs in the Scientific Literature}

This section collects, categorizes, and examines the research conducted on MBMs, as found in the scientific literature.

\subsection{Bunker Levy}

Introducing a levy on bunker fuels is an easy measure to implement and has certainty at the price as shipping companies can act proactively to a known increase in the fuel cost. In their study, $\mathrm{Gu}$ et al. [50] advocate that it is the only strategy that allows the participants to decide a cost-effective way of reducing their emissions without governmental intervention.

Chai et al. [51] support that a levy is more suitable for shipping, regardless of its collection approach, in incentivizing the adoption of technology with high Technology Readiness (TRL), in R\&D investments into low TRL technologies (both of which require stable carbon prices for companies to invest) and in funds generation.

In this regard, Kosmas and Acciaro [52] studied the allocation of the costs from the enforcement of the levy between the ship-owners and shippers, and concluded that the market conditions, the freight rates, and the level of capacity utilization affect it. In their paper, also, they analyzed the economic and environmental implications of two types of levy on shipping bunker fuels; a unit-tax per ton of fuel and an ad-valorem tax enforced as a percentage of fuel prices. Both scenarios lead to speed and a fuel consumption reduction equivalent to an improvement in energy efficiency, and result in the industry's profit decline, the extent of which depends on the structure of the levy and the market conditions. By utilizing the pass-through cost theory (i.e., widely used by many industries to explore cost allocation among the supply chain), the paper concludes that when the market conditions are favorable for the shipping industry, with buoyant demand and high freight rates, cargo beneficiaries will pay a higher percentage of the tax costs and vice versa.

An international fund system has superficially the ability to overcome problems influenced by the inconsistency of the market, simply because the contribution is collected as the fuel is consumed by the ship. Zhao et al. [53] concluded that an insufficient fund caused by a depressed shipping market is unable to work out efficient measures in terms of GHG emissions reduction.

In their study, Lema et al. [54] developed a fuzzy logic model that addresses the proposed MBMs submitted at the IMO. The developed tool synthesizes a large amount of information and compares them with the results of the feasibility study conducted by the expert group at the IMO. The results showed that the GHG Fund and the ETS have similar results in emissions reduction potential, but have a significant difference in cost. More specifically, the study concluded that the GHG Fund could achieve the highest emission reductions with minimum cost.

Devanney [55] investigated the emissions reduction potential of a significant bunker levy. In his study, he estimated that with a price of HFO at USD 465/ton, a bunker levy at USD 50/ton would achieve a $6 \%$ reduction in total Very Large Crude Carrier (VLCC) emissions. A USD 150/ton levy would result in an $11.5 \%$ reduction. Gkonis and Psaraftis [56] estimate the $\mathrm{CO}_{2}$ reductions for tankers and Handymax bulk carriers, for several bunker levy scenarios, and found that a $50 \%$ emission reduction for a single VLCC can be achieved with a fuel price at USD 1000/ton.

The study of Cariou and Cheaitou [57] compared an international bunker levy and speed limits in the EU. The study concludes that, firstly, a regional speed limit does not automatically reduce the amount of $\mathrm{CO}_{2}$ emitted on a global scale, and secondly, by assessing the two options, a regional speed limit is a suboptimal measure than a global levy on bunker fuels. The paper concludes that although an internationally agreed bunker levy is taking too long to agree upon, the IMO policy option, based on 
the polluter, pays for the marginal damage he generates and therefore, remains the preferable option comparing to a speed limit.

The same view is also embraced by Psaraftis [58], who compared speed limits and a bunker levy both on a global scale. The study stated that the speed limits in the short-term could cause an increase in freight rates and thus, benefit the ship-owners instead of inducing them to compensate for the environmental cost of their emissions. Additionally, vessels exceeding in energy efficiency will be forced to sail at the same reduced speed with vessels that have not utilized the same technology and therefore, be punished instead of enjoying the privileges of better fuel efficiency.

Psaraftis and Lagouvardou [59] argued that revenues from a carbon levy could be used to boost $\mathrm{R} \& \mathrm{D}$ and technology deployment. The Norwegian $\mathrm{NO}_{\mathrm{x}}$-fund is an investment $\mathrm{RM}$ (rebate mechanism) that has been applied with excellent results and aims to stimulate the uptake of abatement technology. However, in the case of a low levy, then the industries will not have enough incentives to invest in a new, environmentally friendly technology. The risk of their investment will have a lower return outcome than simply paying the fee. Therefore, the levy's level and the parties that will bear the administrative role of the levy collector are important parameters of the scheme and should be further analyzed.

The same study of Psaraftis and Lagouvardou [59] addressed some of the challenges of implementing a bunker levy in shipping. More specifically, regarding which ships will be subject to the levy, the authors conclude that for competition distortion avoidance, all ships should be subject to the levy, possibly exempting ships of very small size (below 400 GRT). Any exclusion, differentiation, or rebate schemes should be carefully designed and include criteria such as the ship type, size, flag, and age or a benchmark on EEDI, on the attained speed and on any technological advances that are incorporated on the vessel's equipment and therefore, improve their efficiency. The authors also agree that the levy should be a function of the type of fuel used. Fuels with a low carbon footprint should be taxed less in comparison with carbon-intense fuels like fossil fuels. Furthermore, regarding the level of the levy, a low levy between USD 0.5-5/ton of $\mathrm{CO}_{2}$ e would have negligible effects and would mainly raise money for R\&D. A medium levy between USD 5-75/ton of $\mathrm{CO}_{2} \mathrm{e}$ would have moderate effects, whereas a high level of tax of more than USD 75/ton of $\mathrm{CO}_{2} \mathrm{e}$ would achieve more significant results, rendering the alternative fuel solutions more cost-efficient. Besides, regarding the timing of the levy, the study proposes a gradual phase-in schedule starting in 2023 and progressively increasing until 2050. Additionally, regarding the administrative body, the authors do not conclude but list the options (individual body of the IMO scheme based on the International Oil Pollution Compensation Fund (IOPCF)). The final question that the paper tries to address is regarding how and to whom the proceeds of the levy will be distributed. To such a complicated matter, the authors mention the challenges of carbon leakage and competition distortion among the participants, and raise the concerns that strict auditing is needed in any case.

\subsection{Rebate Mechanism (RM) Built into a GHG Fund}

This measure, initially proposed at the IMO by the International Union for the conservation of Nature (IUCN) in 2010 [40], aims in the compensation of developing countries from the financial impact of an MBM. In their paper, Shi et al. [60] conducted a comprehensive assessment of the several proposals submitted at the IMO. Their investigation concluded that among the proposals, the GHG Fund is much more environmentally practical and cost-effective. However, the study supports that the scheme standalone embraces neither the Common But Differentiated Responsibilities (CBDR) and the No More Favorable Treatment (NMFT) principles. Therefore, the authors argue that an add-on Rebate Mechanism built into a global GHG Fund is more likely to be environmentally practical, cost-effective, and feasible. Finally, because it incorporates economic incentives and the CBDR and NMFT principles, it would be more attractive for developing countries. 


\subsection{Global Maritime Emission Trading System (METS)}

The implications of a global METS have attracted the interest of the scientific community. $\mathrm{Gu}$ et al. [50] support that the scheme will incentivize the industry to invest in carbon neutral technology in the long term. Moreover, the increased cost in allowances may force companies to adjust their operational practices by, for example, utilizing slow steaming in the short term. However, other parameters such as bunker prices and charter rates can influence the operational decisions significantly. Therefore, the final total reductions on emissions will rely on the market conditions. The study supports that the implementation of METS can even lead in emissions increase in cases where, for example, bunker prices and charter rates are low, allowances cost is significantly high, or the scheme, instead of being global, is applied on a regional base.

Balcombe et al. [60] support that the implementation of a METS poses various challenges. METS will increase transaction costs related to trading, monitoring, and verification of the allowances for both participants and regulators. This increase in transaction costs, also in combination with a low volume of allowances, will create sub-optimal trading conditions, which may not result in emissions reduction. Another drawback of the system is that developing countries will be burdened by the financial consequences more than their developed counterparts. However, the authors support that precertification and approval of the credits will minimize the risk of carbon leakage. With regards to the utilization of the system by ship-owners, the study claims that borrowing credits must be restricted in order to eliminate the risk of companies simply offsetting emissions and not restricting them. The high volatility of price in a METS will help companies to save in allowances when the price is lower and use them in the future when carbon prices rise again. Finally, the study welcomes any subsidy or rebate mechanism as it could accelerate the transition to low carbon technologies and may also assist in mitigating the economic burden on developing countries.

According to Wang et al. [61], the imposition of a METS implicates a surcharge on the bunker fuel used (from the tramp operator point of view). The induced cost is a product of the trading price of $\mathrm{CO}_{2}$ allowances in the spot market $(\mathrm{P})$ and the emission factor (3.2 tons of $\mathrm{CO}_{2}$ per ton of fuel). Provided that the volume and price of the allowances are both inputs, the incorporation of METS indicated the introduction of an additional fee of $\mathrm{P} \times 3.2$ for each ton of fuel consumed, irrespective of the volume and price of $\mathrm{CO}_{2}$ allowances initially. An increased price of $\mathrm{CO}_{2}$ could induce shipping companies to cut back on long-term contracts or decrease their fleet cover for their increased expenses. This may result in modal changes from short sea shipping to land-based modes of transportation and potential carbon leakage. Setting the emissions and deciding the amount of free allowances given away by public authorities are significant challenges of the system. Companies may purchase allowances through auctioning, and taking advantage of low prices usually comparable to the spot market to avoid meeting their obligations later on where the spot price may fluctuate widely. Both cases can lead to carbon leakage and pose the risk of emissions from shipping to increase.

To that extent, the study of Zis and Psaraftis [62] investigated the various operational measures to mitigate and reverse the potential modal shifts due to environmental legislation. More specifically, the study focused on the short sea shipping segment and examines the effects of higher costs due to compliance with the lower Sulphur requirements in Sulphur Emission Control Areas (SECAs) to the ship's speed. The study concludes that in the case of high fuel prices reducing the sailing speed, along with decreasing the time spent in port, provide higher fuel savings than the loss in revenue. Finally, the study shows that with low fuel prices, the investment in low Sulphur technology has a long payback period even on the most fuel-demanding vessels. Additionally, the study of Okada [63] provides an evaluation of the distance of existing Emission Control Areas' (ECAs) boundaries from seashores and a guideline for setting ECAs. The results can assist in the formulation of a similar regional policy that addresses the $\mathrm{CO}_{2}$ emissions. More specifically, the study concludes that existing ECAs with boundaries farther from the seashore have positive net benefits but might acquire higher net benefits by decreasing the distance. 
The study of Chai et al. [51] focuses on the operational challenges of the scheme. More specifically, the large number of ships trading internationally requires many resources dedicated to setting up, operating and reviewing the system. Moreover, the high variability in each ship's fuel consumption increases the complexity of allowances allocation significantly. The study supports that a METS with full auctioning of credits would be equivalent to a bunker levy in the amount of funds generated. Taking all the above under consideration, the authors conclude that a bunker levy is more effective than METS for regulating shipping.

The study of Lema et al. [64] raised concerns regarding the decision on which MBM should be enforced in shipping as the issue is mainly a political decision. Considering the vast proportion of the global fleet being regulated by developing countries, any MBM enforced shall address their objections.

The study of Tran et al. [65] investigates and ranks the critical success factors (CSF) of sustainable shipping management (SSM) by utilizing a fuzzy analytic hierarch process. The analysis showed that (1) the stakeholders' focus, (2) the intra-firm management, (3) new technology acceptance, (4) the inter-firm collaboration, and (5) the strategic fit are the factors of high importance in descending order. The results can assist in the policy formulation progress and indicate the critical aspects that shipping companies should focus on in order to reach the sustainability goals. To that extent, in their study, Shi et al. [66] argue that due to the staunch opposition of its primary stakeholders, the implementation of METS is infeasible. Their doubts rely on the creation of distortions in international trade. The study also supports that a METS is expected to face significant opposition from developing countries. Current METS proposals at the IMO have incorporated both the CBDR and the NMFT principles, not in a cost-effective way. Norway's approach, for example, incorporates the CBDR principle by providing exemptions for ships below specific sizes and ships on international voyages to SIDS and LDCs.

On a comparative assessment, Psaraftis and Lagouvardou [59] argue that experience from existing ETS applied globally showed a tendency of weak carbon prices due to an oversupply of emissions certificates (i.e., too many allowances were given free of charge, and demand was overestimated, given unforeseen market developments). Additionally, methods to adjust the price were not included in the scheme's architecture. As a result, the price was not strong enough to incentivize the desired investments in low carbon technologies. On the other hand, a carbon levy has stable carbon prices, and therefore, energy producers invest without the fear of volatile regulatory costs. Moreover, in the case that unexpected market conditions lead in significantly low carbon prices, the implementation of a levy has the advantage to establish a specific and continuous price signal, whereas a cap-and-trade does not encourage reductions beyond the emissions target.

Zhu et al. [67], in their study, tried to investigate the effects of METS on a container's fleet operation formation strategies and the respective $\mathrm{CO}_{2}$ emission levels achieved. The results showed that a METS can incentivize operators to implement new technologies on their vessels and invest in renewing instead of retrofitting the existing fleet. More specifically, the authors argue that the ratio of bunker costs to total voyage costs, even at exorbitant $\mathrm{CO}_{2}$ prices, is much higher than the ratio of $\mathrm{CO}_{2}$ allowance expenses to total voyage costs. Therefore, the higher the bunker prices, the more noticeable the impact of a METS will be in achieving the decarbonization targets.

\subsection{Policy Mix Tax on Emissions and Direct Subsidy}

Tanaka et al. [68] developed a model that analyzes the investment behavior of a shipping company, the expected results in fuel efficiency and $\mathrm{CO}_{2}$ emissions after the imposition of a bunker levy. The study shows that a policy mix that comprises of the levy and a direct subsidy is the optimal solution for an international shipping company. Based on a numerical analysis that clarifies the relationships between fuel price, including MBM tax, capital investment, and efforts towards fuel efficiency, the study shows that when the fuel price increases, the firm will seek to improve fuel efficiency and extend voyage distance, considering adequate cargo demand. According to the authors, as the fuel price with a tax increases, $\mathrm{CO}_{2}$ emissions decrease. However, it is possible that, due to the rebound effect, companies will extend their voyage distance in order to earn additional revenue to counteract the financial burden 
caused by the policy. In this case, $\mathrm{CO}_{2}$ emissions can even increase in the long term. Therefore, the level of the levy has a crucial role in the emissions reduction potential and, if set very high, can lead to an increase of the effort cost and, therefore, to a rise in the marginal costs of emission reduction.

The same study argues that a policy mix consisting of a tax on emissions and a direct subsidy can eliminate the rebound risk by rewarding companies for their effort to improve fuel efficiency. Vessels that incorporate energy-efficient technologies to achieve emissions reductions will be funded back by the revenue from the emission tax. This study provides insightful results that can be further analyzed, and incorporates technical information as well as details on actual econometric values that apply in Shipping.

\subsection{Global Tax and Cap}

Miola et al. [69] proposed a Maritime Emission Reduction Scheme (MERS). MERS is a hybrid system that consists of a total $\mathrm{CO}_{2}$ emissions cap and tax on all emissions. Revenues will be collected to a fund and be used in various means, such as for in-sector technical and operational improvements, offset credits purchasing in the emission trading markets, or adaptation mechanisms for developing countries.

The authors examine the case with an emission charge of $40 \%$ of the market price for $\mathrm{CO}_{2}$ allowances and a predetermined cap based on the 2005 emission levels, which decreases by $1 \%$ annually. A tax of USD 10/ton and a global fleet coverage of more than two-thirds, would collect USD 3 billion annually to the fund. According to the report, the levy would lead to total environmental benefits in terms of lower abatement of $15 \mathrm{GT} \mathrm{CO}_{2}$ before 2050 due to the technical and operational industry improvements and $8 \mathrm{Gt} \mathrm{CO}_{2}$ due to emission offsets. The proposed scheme outweighs a global METS as it avoids the operational costs of setting up, monitoring and reviewing of a global trade system.

\subsection{Global Sectoral Crediting}

Miola et al. [69] investigated a Maritime Sector Crediting Mechanism (MSCM), a voluntary scheme utilizing baselines for the entire sector's emissions. A reduction of emissions below that baseline will generate tradable credits for the whole sector. Creating carbon marketable incentivizes the industry to reduce the $\mathrm{CO}_{2}$ emissions, but due to the voluntary nature of the scheme, there is no enforcement to support the system. Generally, this mechanism aims to encourage developing countries to engage in GHG emissions reduction. Since, according to the system's architecture, there is a need for demand in offsetting credits, MSCM can only be enforced as complementary to a cap-and-trade system. As MSCM is voluntary, the supply and demand of credits from this system is highly erratic.

\subsection{EU ETS}

The inclusion of shipping in the EU ETS has been examined by Miola et al. [69]. Regional policies, such as at a European level, face several obstacles when enforced in international sectors like, for example, emissions allocation, carbon leakage, allocation of permits, handling the great diversity of ship types, sizes, and fuel consumption, and unpredictable transaction costs. The above aspects, and with the fact that ships can easily change their jurisdiction under a flag of convenience, have set barriers to the United Nations Framework Conference on Climate Change (UNFCCC) and the IMO to implement a clear-cut GHG reduction policy.

More specifically, the study argues that both global and regional trading policies may induce high transaction costs. As economies of scale emerge, this issue can affect more ships with low carbon emissions and result in raising the cost of European shipping along with creating competitive distortion in the whole sector naturally. Therefore, excluding small installations from their monitoring and reporting requirements by minimizing, for example, the frequency of compulsory inspection visits or by exempting them from the trading system altogether, can be beneficial for the implementation of an ETS. However, anticipating and integrating these dynamic issues under the NMFT principle for all 
ships would possibly manage to address possible challenges for vessels regarding compliance with the legislation.

Wang et al. [70] argued that the implementation of a regional scheme could induce competition distortions. For example, risks of route networks' reconfiguration are significantly crucial. In this way, ships can avoid compensation for their emissions in an EU ETS scenario. The hypothetical case includes transshipments in the port of Dubai right before entering the EU ETS waters. This would lead to adjustments in frequency, voyage distance, and fuel consumption of vessels, and render Dubai a developed hub. It would be beneficial for the scope of the analysis if extended models were created that take into consideration additional inputs that include the outcomes and trade-offs between conformity and carbon leakage under a regional ETS. The model shall incorporate a stochastic demand specification since market conditions in shipping are incredibly uncertain. However, within the framework of this study, a static economic model is developed that investigates the effects of ETS under current market conditions, global competition, and available technology. The results show that companies can alter their energy efficiency either through building new vessels (longer to mediumterm) or by incorporating energy efficiency operational measures (short-term). However, more accurate conclusions regarding the response of the industry in an EU ETS scenario should be further investigated using dynamic models that address the related managerial decisions.

The study of Koesler et al. [71] addresses the inclusion of Shipping in the EU ETS from an economic and a legal point of view. The authors analyze the research question using a general equilibrium approach. The results showed that economic-wise implementing a regional scheme would burden disproportionately the routes on EU territorial waters and impede cost-efficient emission abatement among regulated ships. Furthermore, from a legal point of view, the study claims that an EU ETS violates the World Trade law and poses a serious dilemma for future inclusion of shipping in the scheme.

\section{Market-Based Measures in the Grey Literature}

The following sections refer to research conducted on the field of MBMs by organizations outside of the traditional academic publishing. The paper investigates various aspects arising from the introduction of an MBM and constitutes up-to-date research material on the topic. Therefore, these may be helpful in the development of a holistic approach to MBMs for shipping.

\subsection{BHP Group Limited BW Group DNB DNV GL—Carbon Levy Evaluation 2019}

The report [72] examines whether a levy on bunker fuels can be an effective way to reduce GHG emissions from shipping. The report highlights that substantial decarbonization needs a carbon pricing mechanism that provides disincentives for the consumption of carbon-intensive fuels and incentives for R\&D.

The report argues that in comparison with an ETS, a bunker levy is a more structured and transparent mechanism as it consists of a predetermined contribution that will stimulate the uptake of abatement technology at an early stage. Proceeds should be deployed for research, trials, implementation, and scaling of alternative fuels and zero-carbon technology to ensure that cost to the buyer reduces over time. When collected by a supranational entity like IMO, the risk of carbon leakage among the states is reduced. Finally, revenues generated by the levy can be distributed to the UNFCCC Green Climate Fund (GCF) and the UN Global Environment Facility (GEF).

\subsection{IMF-Carbon Taxation for International Maritime Fuels: Assessing the Options 2018}

The report of the International Monetary Fund (IMF) [73] concludes that a carbon tax is preferable to a trading system or other offsetting mechanism because it provides certainty over prices, is simpler to administer, and leads towards technological and operational opportunities for both new and existing vessels. Taxes should be collected at an international level through the establishment of a fund administered by the IMO. Rates should be following other pricing schemes (around USD 5-30 $\mathrm{t} / \mathrm{CO}_{2}$ ) for avoiding distortions in completion among transportation modes. 
The report studies the establishment of a carbon tax starting at USD 75 per ton of $\mathrm{CO}_{2}$ in 2030 (USD 240 per ton of bunker fuel) and rising to USD 150 per ton in 2040. Results show emissions below business-as-usual (BAU) reduced by $15 \%$ in 2030 and by $25 \%$ in 2040, total revenues gathered about USD 75 billion in 2030, and USD 150 billion in 2040 while shipping costs increased by $0.075 \%$ of GDP in 2030 .

The report highlights that establishing a performance standard (EEDI) for new ships has only one-third of the effectiveness of carbon taxes (for the implied $\mathrm{CO}_{2}$ price). Finally, regarding compensation mechanisms for developing countries, the report proves that because the financial burden of maritime carbon taxation is generally small concerning countries' GDP, any global enforcement of the tax should be feasible.

\subsection{WBG - Understanding the Economic Impact of Greenhouse Gas Mitigation Policies on Shipping 2019}

A working paper of the World Bank Group [74] investigates the economic impacts of various GHG mitigation measures on states, using model-based analysis. Specifically, the results of the analysis show that the enforcement of GHG mitigation measures will raise transportation costs and import prices of goods, and will minimize the number of commodities traded internationally. Based on that, the study focuses on the impact of a carbon price applied to bunker fuels on state gross domestic product (GDP) and concludes that in the range of USD 10-50/ton of $\mathrm{CO}_{2}$, transport costs will increase by $0.4 \%$ to $16 \%$. This increase, however, would only marginally raise the import prices of goods (by less than 1\%). Therefore, the impact of a carbon price set between USD 10-90/ton of $\mathrm{CO}_{2}$ on national economies is expected to be modest $(-0.002 \%$ to $-1 \%$ of GDP).

\subsection{New Climate Institute—Carbon Pricing Options for International Maritime Emissions 2019}

The New Climate Institute report [75] on behalf of the German Federal Ministry for the Environment, Nature Conservation, and Nuclear Safety, study three different options for an MBM for international shipping, utilizing four criteria for choosing the appropriate scheme.

The examined MBMs are (i) an offsetting scheme that requires ships to pay for their GHG emissions by purchasing emission reduction credits, (ii) a METS that places a cap on the total GHG emissions and allows companies to trade their credits and (iii) a "climate levy" that places a price on every ton of GHG emitted from ships.

The report concludes that a climate levy imposed at an appropriate price level is most likely to lead the sector in reaching its decarbonization targets, can address both the NMFT and CBDRRC principles, and has significantly lower transaction costs than the other options. A "climate levy" that increases progressively based on the cost difference of alternative and fossil fuels can induce the change needed towards no fossil fuels. Compared to a METS, a "climate levy" provides foreseeable and stable price signals, which leads to greater certainty over investments in low carbon technologies. Furthermore, a METS is more of a composite measure to apply, and the experience of highly volatile prices is likely to provide investors with a clear carbon price incentive. Additionally, a METS can lead to market manipulation since the six largest companies that have a market share of $50 \%$ can have significant effects on transaction costs.

\subsection{UMAS- $\mathrm{CO}_{2}$ Emissions from International Shipping, Possible Reduction Targets, and Their Associated Pathways 2016}

The report published by UMAS [19] aims to investigate the potential routes and scenarios in the context of broader decarbonization consistent with the Paris Agreement (COP21). The study investigates various cases with targets ranging from achieving full decarbonization by around 2035 (temperature stabilization 1.5 degrees above pre-industrial levels) to keeping $\mathrm{CO}_{2}$ emissions from shipping at current levels.

This study considers a selection of assumptions to simulate how the shipping sector will evolve to meet the examined targets in its total $\mathrm{CO}_{2}$ emissions. The model runs from 2010 until 2050 in the 
baseline year of 2010 and stimulates the evolving decisions made by different stakeholders in the industry. The model uses a carbon price to achieve the specified reduction goal for $\mathrm{CO}_{2}$ emissions. The results from the simulations show that with no further policy, expectations are that $\mathrm{CO}_{2}$ emissions from international shipping will rise by at least $50 \%$. Shipping would need to decrease its total carbon intensity by more than can be accomplished with energy measures alone, in order to achieve absolute reductions while meeting an expected increase in transport demand. The study also suggests that the use of extremely low operating speeds in conjunction with fossil fuels is preferable to renewable fuels such as biofuels and hydrogen, along with energy efficiency interventions. As for the offsetting schemes, the study shows that it is quite dangerous to assume that shipping decarbonization can be achieved entirely through offsets because their high volatile price can even lead to increased emissions.

\subsection{Transport and Environment-EU Shipping's Climate Record: Maritime $\mathrm{CO}_{2}$ Emissions and Real-World Ship Efficiency Performance 2019}

The report of Transport and Environment [76] gathers and analyzes raw ship performance data from the EU Shipping MRV for translating them into policy, relevant and transparent to the relatable public knowledge information. The study reveals that the container shipping operator, Mediterranean Shipping Company (MSC), together with coal power plants, are on the list of the top $10 \mathrm{EU}$ emitters for 2018. The company is responsible for 11 million tons of $\mathrm{CO}_{2}$ from operations falling under the $\mathrm{EU}$ MRV scope. If shipping was part of the EU ETS, the report claims that MSC would be the EU's 8th most emitting operator.

Furthermore, the report compares the amount of $\mathrm{CO}_{2}$ emitted by ships traveling to or from some EU countries with the amount of $\mathrm{CO}_{2}$ emitted by the total national passenger cars of those countries. There are many examples of EU Members where the shipping emissions attributed to their ports are more significant or comparable with the total amount of $\mathrm{CO}_{2}$ emitted from passenger cars. Therefore, not regulating shipping emissions not only exempts abundant sources of $\mathrm{CO}_{2}$ in major European cities and countries but also obliterates the decarbonization gains achieved by other sectors.

Finally, the report recommends including EU shipping in the ETS to ensure that the sector will compensate for its carbon pollution. Despite that EU ETS has been characterized by low carbon prices and has failed to bring the expected technological innovation, experience with the scheme allows the policymakers to re-design it in a way that maximizes its practical relevance. The establishment of a European Maritime Climate Fund (MCF) under the EU ETS, in which ships would pay directly to the fund a $\mathrm{CO}_{2}$ levy proportionate to their MRV emissions, is also a suggested solution according to the report. Responding to tax allocation challenges, the authors conclude that in 50 euros per ton of $\mathrm{CO}_{2}$ price scenario, the extra amount paid by the consumers would be insignificant and a maximum of $0.55 \%$ of their initial price.

\subsection{UNCTAD Data and Reports}

In February 2020, UNCTAD published a study that estimates the fleet renewal trends in shipping based on scrapping patterns [77]. Motivated by the recent statements of the Getting To Zero Coalition, of the urge for commercially viable zero emission vessels to enter the global fleet by 2030 in order to reach the decarbonization targets, the study used past scrapping patterns to show the future expected trend on demolitions. The study concluded that regardless of the percentages of the different type of vessels being demolished until 2030, new buildings are not likely to burn alternative fuels by 2030 . Therefore, the sector is urged to develop, implement and test the appropriate technology in order to meet the decarbonization targets.

Furthermore, in March 2020, another study of UNCTAD [78] focused on the regulatory role of Flag States for enforcing the IMO rules on GHG emissions. Except from validating the compliance of the vessel with the regulations on emissions, each Flag State could provide individual incentives for ships under their jurisdiction to promote decarbonization. Major Flag States such as Panama, Liberia and Marshall Islands are significantly affected by the impacts of climate change and have a self-interest on 
applying the respective regulations. The aforementioned Flag States accounted for approximately 33\% of global $\mathrm{CO}_{2}$ emissions from shipping in 2019 and represented $34.86 \%$ of the world gross tonnage the same year. The study aims to encourage discussions on the role of Flag States for regulating the $\mathrm{CO}_{2}$ emissions, and quantifies that commercial ships above 1000 DWT registered in the top 10 economies accounted for $67.15 \%$ of maritime $\mathrm{CO}_{2}$ emissions. As of 1 January 2020, these 10 Flag States own $48.52 \%$ of the world fleet and $65.73 \%$ of the world gross tonnage. Finally, the study indicates that maritime $\mathrm{CO}_{2}$ emissions have risen by $8 \%$ from 2014 to 2019 and $\mathrm{CO}_{2}$ emissions among the top 10 Flag States have risen more steeply by $14 \%$.

\section{Conclusions}

Before we proceed with the conclusions, Table 2 summarizes the MBMs as suggested in the scientific and grey literature (Sections 3 and 4 respectively), along with the relevant references, and broken down into two main classes: fuel levy and variants, and ETS and variants.

Table 2. Summary table of Market Based Measuress suggested in the Scientific and Grey Literature and Relevant References.

\begin{tabular}{ll}
\hline \multicolumn{1}{c}{ MBMs } & \multicolumn{1}{c}{ Relevant References } \\
\hline Fuel Levy and variants & {$[19,40,50-59,68,72-75]$} \\
\hline Emission Trading System (ETS) and variants & {$[19,50,51,59-61,64,66,67,69-76]$} \\
\hline
\end{tabular}

The Initial IMO Strategy sets substantial emissions reduction targets and depicts the eager vision of the Industry towards a decarbonized future. The essential tools for achieving these goals are described as "candidate short-, mid-, and long-term measures." This paper aimed at collecting and analyzing an updated literature on MBMs that, as described in the Initial IMO Strategy, fall into the set of the mid-term candidate measures. MBMs are flexible mechanisms that use market prices and other economic variables to incentivize for emissions reduction. MBMs also force the polluters to compensate for the cost of their emissions, and thus, they internalize the external environmental cost of polluting. Examples of MBMs are the environmental taxes, the provision of subsidies, various offsetting mechanisms, and the ETS.

Substantial or full decarbonization of shipping needs pluralistic and concrete solutions. MBMs can induce changes both in the operational and technological levels and, therefore, are related to both the short- and long-term candidate measures needed to achieve the targets set by IMO. Until January 2013, shipping had not been included in any legally binding treaty despite its significant contribution to climate change. The EEDI and SEEMP were the first mandatory measures for new buildings and existing vessels that took into consideration the implementation of energy-efficient equipment in the vessel's machinery along with the utilization of operational advances like route optimization and weather routing that increase the energy efficiency during the voyage. However, recent studies showed that the measures could not have significant results in reducing emissions as full coverage of the fleet will happen several years after the enforcement and the expected growth in the maritime world trade will increase the emissions disproportionately. Thus, substantial decarbonization of the shipping sector calls for a rapid maneuver towards zero-carbon technologies and alternative fuels.

Emissions from shipping are expected to grow significantly until 2050 if no action is taken. Such forecasts urge for the adoption of the appropriate regulatory tools. The European Commission's commitment to tackle climate change led to the communication of the European Green Deal, which, among others, emphasizes the need for the EU ETS to act as the essential regulatory tool on reducing emissions from shipping. However, the industry opposes their inclusion in the system as previous experience from the aviation industry, along with historical low/zero-carbon prices, revealed that regional rules could not regulate international sectors adequately. Furthermore, various stakeholders 
are concerned that EU ETS will distort competition and will result in carbon leakage as well as create a high administrative burden for the Industry.

The impact of inducing discriminations in international trade by the inclusion of shipping in the EU ETS led some researchers to focus on investigating the establishment of a Global METS. However, the system appears hard to operationalize as the large number of ships trading internationally requires many resources dedicated to setting up, operating, and reviewing the system. Additionally, a Global METS that does not provide certainty in the price of allowances will result in firms simply offsetting the emissions rather than reducing them. Finally, there are concerns regarding market distortion on transaction costs since the six largest shipping companies at the moment are having a market share of $50 \%$.

A bunker levy measure was proposed to the IMO in the form of a contribution to the GHG international fund. The option has been widely supported by the scientific community as it has certainty at a price in terms of an increase in the fuel cost to which the shipping community can act proactively. Therefore, a bunker levy that increases the cost of carbon-intense energy solutions renders low carbon technologies more alluring; and meanwhile, can assist in improving the essential infrastructure for resolving any technical barriers for their implementation. Studies showed that a tax on marine fuels would immediately induce speed and fuel consumption reductions leading to emissions reductions. However, caution should be raised in the case of a low level of the levy, which will not have any substantial result in the short term as it does not provide enough incentives for investments in low carbon technologies. Taking into consideration the inconsistent structure of the shipping market, a levy collected through bunker fuel suppliers can act effectively in terms of enforcement as it is simple to administer.

As this paper was being finalized, the COVID-19 pandemic created a significant upheaval in global trade flows, cargo demand, and fuel prices. The global and regional reduction of production, consumption, trade and hence, shipping and port activity, is very real and will result in corresponding real reductions in GHG emissions, at least in the short to medium term. At the same time, the unprecedented drop in fuel prices as a result of COVID-19 may act as a serious counterweight and may make GHG reductions more difficult, and, in fact, at two levels. At the operational/logistics/short-term level, ships may be encouraged to sail faster than before due to fuel being so much cheaper, thus increasing $\mathrm{CO}_{2}$ emissions per transport work. Large container carriers were sending ships around Africa at higher speeds as this is cheaper than going through Suez. This may make sense from an economic perspective, but it is not good on the GHG front.

Even more serious may be the situation at the strategic/technological/long-term level. A question is, who will choose to invest in energy saving technologies or in alternative, low carbon fuels when fossil fuel prices are rock bottom? Even under pre-COVID-19 fuel prices, many such technologies or fuels were not viable, and hence, the need to introduce MBMs to incentivize their future development was very clear. We believe that this need is more clear now. However, if the MBM discussion had not yet started at the IMO under normal circumstances, will it start now under the COVID-19 or postCOVID-19 turmoil? The EU Green Deal may provide a stimulus for this to happen at the IMO level. How this will play out is not yet clear. So, substance-wise and also timing-wise, we believe that the key findings of the paper can assist progress on the MBM front and encourage the IMO discussions on environmental policies to reduce GHG emissions.

Our ongoing research agenda entails a comprehensive analysis of MBM alternatives, including a carbon levy and an ETS, and a comparison of these alternatives according to specified criteria, with a view to meeting the IMO GHG reduction targets in the best possible way. This analysis will be reported in future publications.

Author Contributions: Conceptualization, S.L.; Methodology, S.L.; Investigation, S.L.; Writing一original draft preparation, S.L.; Writing-review and editing, S.L., H.N.P. and T.Z.; Visualization, S.L.; Funding acquisition, H.N.P. All authors have read and agreed to the published version of the manuscript. 
Funding: Work on this paper has been supported by the MBM SUSHI project, funded by the Orients Fund and DTU.

Acknowledgments: We would like to thank four anonymous reviewers for their comments on a previous version of the paper. We are also grateful to (alphabetically) Bo Larsen of Danish Shipping, Jan Hoffmann of UNCTAD and Poul Woodall of DFDS for their comments which helped improve the paper.

Conflicts of Interest: The authors declare no conflicts of interest.

\section{References}

1. Helm, D. The assessment: Climate-change policy. Oxf. Rev. Econ. Policy 2003, 19, 349-361. [CrossRef]

2. Ehlers, S.; Asbjørnslett, B.E.; Rødseth, Ø.J.; Berg, T.E. Maritime-Port Technology and Development; CRC Press/ Balkema: EH Leiden, The Netherlands, 2014.

3. Guerin, K. Property Rights and Environmental Policy: A New Zealand Perspective. 2003. Available online: http://ideas.repec.org/p/nzt/nztwps/03-02.html (accessed on 25 March 2020).

4. Financial Matters: Proposals for Long-Term Financing of the Integrated Co-Operation Programme; TC 41/7(c) (1995) Note by the Secretariat; IMO: London, UK, 1995.

5. Skjolsvik, K.; Andersen, A.; Corbett, J.; Skjelvik, J. Study of Greenhouse Gas Emissions from Ships Final Report to the International Maritime Organization. 2000. Available online: http://citeseerx.ist.psu.edu/ viewdoc/download? (accessed on 25 March 2020).

6. Full Report of the Work Undertaken by the Expert Group on the Feasibility Study and Impact Assessment of Possible Market-Based Measures; IMO doc. MEPC 61/INF.2; IMO: London, UK, 2010.

7. Initial IMO Strategy on Reduction of GHG Emissions from Ships; MEPC. 304(72); IMO: London, UK, 2018.

8. EU. The European Green Deal EN. In Proceedings of the Communication from the Commission to the European Parliament, the European Council, the Council, the European Economic and Social Committee and the Committee of the Regions, London, UK, 30 March 2019. [CrossRef]

9. DRAFT REPORT on the Proposal for a Regulation of the European Parliament and of the Council amending Regulation (EU) 2015/757 in Order to Take Appropriate Account of the Global Data Collection System for Ship Fuel oil Consumption Data (COM(2019)0038-C8- (Vol. 0017). Available online: https://www.europarl. europa.eu/doceo/document/ENVI-PR-646870_EN.pdf (accessed on 25 March 2020).

10. Smith, T.; O'Keeffe, E.; Aldous, L.; Parker, S.; Raucci, C.; Trau, M.; Anderson, B.; Agrawal, A.; Ettinger, S.; Corbett, J.; et al. Third IMO Greenhouse Gas Study; International Maritime Organization (IMO): London, UK, 2014; Volume 3. Available online: http://www.imo.org/en/OurWork/Environment/PollutionPrevention/ AirPollution/Documents/ThirdGreenhouseGasStudy/GHG3ExecutiveSummaryandReport.pdf (accessed on 25 March 2020).

11. Wang, X.; Yuen, K.F.; Wong, Y.D.; Li, K.X. How can the maritime industry meet Sustainable Development Goals? Transp. Res. Part D 2020, 78, 102173. [CrossRef]

12. DNV GL. Maritime Forecast to 2050 Energy Transition Outlook 2019. 2019. Available online: https: //eto.dnvgl.com/2019/Maritime/forecast (accessed on 25 March 2020).

13. Buhaug, Ø.; Corbett, J.J.; Endresen, Ø.; Eyring, V.; Faber, J.; Hanayama, S.; Lee, D.S.; Lee, D.; Lindstad, H.; Markowska, A.Z.; et al. Second IMO GHG Study 2009. 2009. Available online: http://www.imo.org/en/OurWork/Environment/PollutionPrevention/AirPollution/Documents/ SecondIMOGHGStudy2009.pdf (accessed on 25 March 2020).

14. Eide, M.S.; Endresen, Ø.; Skjong, R.; Longva, T.; Alvik, S. Cost-effectiveness assessment of CO2 reducing measures in shipping. Marit. Policy Manag. 2009, 36, 367-384. [CrossRef]

15. Faber, J.; Wang, H.; Nelissen, D.; Russel, B.; St Amand, D. Marginal Abatement Costs and Cost Effectiveness of Energy-Efficiency Measures Submitted; IMO: London, UK, 2011; Volume 61.

16. Gilbert, P. From reductionism to systems thinking: How the shipping sector can address sulphur regulation and tackle climate change. Mar. Policy 2014, 43, 376-378. [CrossRef]

17. Lindstad, H.E. Hydrogen the next maritime fuel. In Proceedings of the Shipping in Changing Climates Conference 2015, Glasgow, UK, 10-11 November 2015.

18. Shi, Y.; Gullett, W. International Regulation on Low-Carbon Shipping for Climate Change Mitigation: Development, Challenges, and Prospects. Ocean Dev. Int. Law 2018, 49, 134-156. [CrossRef] 
19. Smith, T.; Raucci, C.; Haji Hosseinloo, S.; Rojon, I.; Calleya, J.; De La Fuente, S.; Wu, P.; Palmer, K. $\mathrm{CO}_{2}$ Emissions from International Shipping Possible Reduction Targets and Appendix and Operational Intervention Assumptions. 2016. Available online: https:/u-mas.co.uk/LinkClick.aspx?fileticket= na3ZeJ8Vp1Y\%3D\&portalid=0 (accessed on 25 March 2020).

20. IMO. The Energy Efficiency Design Index (EEDI) and Underpowered Ships; IMO doc, MEPC 60/4/17; IMO: London, UK, 2010.

21. Psaraftis, H.N.; Woodall, P. Reducing GHGs: The MBM and MRV Agendas. Sustain. Shipp. 2019, $375-405$. [CrossRef]

22. EU. COMMISSION STAFF WORKING DOCUMENT Accompanying the Document Proposal for a Regulation of the European Parliament and of the Council on the Monitoring, Reporting and Verification of Carbon Dioxide Emissions from Maritime Transport and Amending Regulation (EU) N ${ }^{\circ}$ 525/2013. 2013. Available online: https:/ec.europa.eu/clima/sites/clima/files/transport/shipping/docs/swd_2013_236_en.pdf (accessed on 25 March 2020).

23. Faber, J.; Huigen, T.; Nelissen, D. Regulating Speed: A Short-term Measure to Reduce Maritime GHG Emissions. 2017. Available online: www.cedelft.eu (accessed on 25 March 2020).

24. Christodoulou, A.; Gonzalez-Aregall, M.; Linde, T.; Vierth, I.; Cullinane, K. Targeting the reduction of shipping emissions to air. Marit. Bus. Rev. 2019, 4, 16-30. [CrossRef]

25. Cariou, $\mathrm{P}$. Is slow steaming a sustainable means of reducing $\mathrm{CO} 2$ emissions from container shipping? Transp. Res. Part D 2011, 16, 260-264. [CrossRef]

26. Corbett, J.J.; Wang, H.; Winebrake, J.J. The effectiveness and costs of speed reductions on emissions from international shipping. Transp. Res. Part D 2009, 14, 593-598. [CrossRef]

27. Lindstad, H.; Asbjørnslett, B.E.; Strømman, A.H. Reductions in greenhouse gas emissions and cost by shipping at lower speeds. Energy Policy 2011, 39, 3456-3464. [CrossRef]

28. Shi, W.; Xiao, Y.; Chen, Z.; McLaughlin, H.; Li, K.X. Evolution of green shipping research: Themes and methods. Marit. Policy Manag. 2018, 45, 863-876. [CrossRef]

29. Psaraftis, H.N. Market-based measures for greenhouse gas emissions from ships: A review. Wmu J. Marit. Aff. 2012, 11, 211-232. [CrossRef]

30. The International Fund for Greenhouse Gas Emissions from Ships (GHG Fund) Proposed by Cyprus, Denmark, the Marshall Islands, Nigeria, and IPTA; IMO doc. MEPC 60/4/8; IMO: London, UK, 2010.

31. The Global Emission Trading System (ETS) for International Shipping Proposal by Norway; IMO doc. MEPC 60/4/22; IMO: London, UK, 2010.

32. Global Emissions Trading System (ETS) for International Shipping Proposal by the United Kingdom; IMO doc. MEPC 60/4/26; IMO: London, UK, 2010.

33. Further Elements for the Development of an Emissions Trading System (ETS) for International Shipping Proposal by France; IMO doc. MEPC 60/4/41; IMO: London, UK, 2010.

34. Design and Implementation of a Worldwide Maritime Emission Trading Scheme. Results of a Scientific Study; IMO doc. MEPC 63/5/9; IMO: London, UK, 2011.

35. The Leveraged Incentive Scheme (LIS) to Improve the Energy Efficiency of Ships Based on the International GHG Fund Proposed by Japan; IMO doc. MEPC 60/4/37; IMO: London, UK, 2010.

36. The United States Proposal to Reduce Greenhouse Gas Emissions from International Shipping, the Ship Efficiency, and Credit Trading (SECT); IMO doc. MEPC 60/4/12; IMO: London, UK, 2010.

37. Vessel Efficiency System (VES) Proposal by the World Shipping Council; IMO doc. MEPC 60/4/39; IMO: London, UK, 2010.

38. Market-Based Instruments: A Penalty on Trade and Development, Proposal by the Bahamas; IMO doc. MEPC 60/4/10; IMO: London, UK, 2010.

39. Achieving a Reduction in Greenhouse Gas Emissions from Ships through Port State Arrangements Utilizing the Ship Traffic, Energy and Environment Model, STEEM (PSL) Proposal by Jamaica; IMO doc. MEPC 60/4/40; IMO: London, UK, 2010.

40. A Rebate Mechanism (RM) for a Market-Based Instrument for International Shipping Proposal by IUCN; IMO doc. MEPC 60/4/55; IMO: London, UK, 2010.

41. How Technical and Operational Measures are the Only Direct and Effective Means to Deliver Cuts in $\mathrm{CO}_{2}$ Emissions; IMO doc. GHG-WG 3/2; IMO: London, UK, 2011. 
42. Consolidated Proposal of "Efficiency Incentive Scheme" Based on the Leveraged Incentive Scheme and the Vessel Efficiency System; IMO doc. GHG-WG 3/3/2; IMO: London, UK, 2011.

43. Proposal to Include Work on Market-Based Measures in the Program of Follow-up Actions of the Initial IMO GHG Strategy Submitted by France; IMO: London, UK, 2018.

44. Action Plan for Implementing the IMO GHG Strategy and Candidate Measures Submitted by Antigua and Barbuda, Kenya, Marshall Islands, Palau, Solomon Islands, Tonga, Tuvalu ISWG-GHG 4/2/3; IMO: London, UK, 2018.

45. The Need for a Flexible Compliance Mechanism Submitted by Norway; IMO doc. ISWG-GHG 6/7; IMO: London, UK, 2019.

46. Proposal to Establish an International Maritime Research and Development Board (IMRB) by ICS, Bimco, Clia, Intercargo, Interferry, Intertanko; IPTA, and WSC MEPC 75/7/4; IMO: London, UK, 2020.

47. EC 2013, Proposal from the Commission to the European Parliament and Council for the Inclusion of GHG Emissions from Maritime Transport in the EU's Reduction Commitments Impact Assessment (Parts I II). Available online: https://doi.org/10.1017/CBO9781107415324.004 (accessed on 25 March 2020).

48. Ricardo-AEA; Milieu; IHS; AMEC; Marintek. Support for the Impact Assessment of a Proposal to Address Maritime Transport Greenhouse Gas Emissions, Report for European Commission-DG Climate Action. 2013. Available online: http://ec.europa.eu/clima/policies/transport/shipping/studies_en.htm (accessed on 25 March 2020).

49. Hermeling, C. Sailing into a Dilemma. Transp. Res. Part A 2015, 78, 34-53. [CrossRef]

50. Gu, Y.; Wallace, S.W.; Wang, X. Can an Emission Trading Scheme really reduce CO2 emissions in the short term? Evidence from a maritime fleet composition and deployment model. Transp. Res. Part D 2019, 74, 318-338. [CrossRef]

51. Chai, K.-H.; Lee, X.N.; Gaudin, A. A Systems Perspective to Market-Based Mechanisms (MBM) Comparison for International Shipping. Ssrn Electron. J. 2019. [CrossRef]

52. Kosmas, V.; Acciaro, M. Bunker levy schemes for greenhouse gas (GHG) emission reduction in international shipping. Transp. Res. Part D 2017, 57, 195-206. [CrossRef]

53. Zhao, J. Analytical Review of Market-Based Measures for Reducing Marine GHG Emissions and the Impacts on the Chinese Shipping Sector. Ph.D. Thesis, World Maritime University, Malmö, Sweden, 2011.

54. Lema, E.; Karaganis, A.; Papageorgiou, E. A Fuzzy Logic Modeling of Measures Addressing Shipping $\mathrm{CO}_{2}$ Emissions. J. Intell. Syst. 2017, 26, 439-455. [CrossRef]

55. Devanney, J.W. The Impact of EEDI on VLCC Design and CO2 Emissions. Center for Tankship Excellence, USA, 2010. Available online: www.c4tx.org (accessed on 25 March 2020).

56. Gkonis, K.G.; Psaraftis, H.N. Modeling tankers' optimal speed and emissions. Sname Trans. 2012, 120, 90-115.

57. Cariou, P.; Cheaitou, A. The effectiveness of a European speed limit versus an international bunker-levy to reduce $\mathrm{CO}_{2}$ emissions from container shipping. Transp. Res. Part D 2012, 17, 116-123. [CrossRef]

58. Psaraftis, H.N. Decarbonization of maritime transport: To be or not to be? Marit. Econ. Logist. 2019, 21, 353-371. [CrossRef]

59. Psaraftis, H.N.; Lagouvardou, S. Market Based Measures for the reduction of Green House Gas Emissions from ships: A possible way forward. Samfundsoekonomen 2020, 4, 60-70.

60. Balcombe, P.; Brierley, J.; Lewis, C.; Skatvedt, L.; Speirs, J.; Hawkes, A.; Staffell, I. How to decarbonise international shipping: Options for fuels, technologies and policies. Energy Convers. Manag. 2019, 182, 72-88. [CrossRef]

61. Wang, X.; Norstad, I.; Fagerholt, K.; Christiansen, M. Green Tramp Shipping Routing and Scheduling: Effects of Market-Based Measures on CO2 Reduction. Sustain. Shipp. 2019, 285-305. [CrossRef]

62. Zis, T.; Psaraftis, H.N. Operational measures to mitigate and reverse the potential modal shifts due to environmental legislation. Marit. Policy Manag. 2019, 46, 117-132. [CrossRef]

63. Okada, A. Benefit, cost, and size of an emission control area: A simulation approach for spatial relationships. Marit. Policy Manag. 2019, 46, 565-584. [CrossRef]

64. Lema, E.; Papaioanou, D. Policy instruments and recent advances of the greenhouse gas regulating framework in shipping. Interdiscip. Environ. Rev. 2013, 14, 238. [CrossRef]

65. Tran, T.M.T.; Yuen, K.F.; Li, K.X.; Balci, G.; Ma, F. A theory-driven identification and ranking of the critical success factors of sustainable shipping management. J. Clean. Prod. 2020, 243. [CrossRef]

66. Shi, Y. Reducing greenhouse gas emissions from international shipping: Is it time to consider market-based measures? Mar. Policy 2016, 64, 123-134. [CrossRef] 
67. Zhu, M.; Yuen, K.F.; Ge, J.W.; Li, K.X. Impact of maritime emissions trading system on fleet deployment and mitigation of $\mathrm{CO}_{2}$ emission. Transp. Res. Part D 2018, 62, 474-488. [CrossRef]

68. Tanaka, H.; Okada, A. Effects of market-based measures on a shipping company: Using an optimal control approach for long-term modeling. Res. Transp. Econ. 2019, 73, 63-71. [CrossRef]

69. Miola, A.; Marra, M.; Ciuffo, B. Designing a climate change policy for the international maritime transport sector: Market-based measures and technological options for global and regional policy actions. Energy Policy 2011, 39, 5490-5498. [CrossRef]

70. Wang, K.; Fu, X.; Luo, M. Modeling the impacts of alternative emission trading schemes on international shipping. Transp. Res. Part A 2015, 77, 35-49. [CrossRef]

71. Koesler, S.; Achtnicht, M.; Köhler, J. Course set for a cap? A case study among ship operators on a maritime ETS. Transp. Policy 2015, 37, 20-30. [CrossRef]

72. BHP Group; Limited BW Group; DNB; DNV GL-Maritime. Carbon Levy Evaluation-Could a Carbon Levy in Shipping be an Effective Way to Help; Global Maritime Forum: Singapore, 2019.

73. Parry, I.; Heine, D.; Kizzier, K.; Smith, T. Carbon Taxation for International Maritime Fuels: Assessing the Options. Imf Work. Pap. 2018, 18. [CrossRef]

74. Halim, R.A.; Smith, T.; Englert, D. Understanding the Economic Impacts of Greenhouse Gas Mitigation Policies on Shipping-What Is the State of the Art of Current Modeling Approaches? 2019. Available online: http://tiny.cc/econ-model-ship-exec-sum (accessed on 25 March 2020).

75. Kachi, A.; Mooldijk, S.; Warnecke, C. Carbon Pricing Options for International Carbon Pricing Options for International Maritime Emissions. 2019. Available online: https:/newclimate.org/2019/03/19/carbon-pricingoptions-for-international-maritime- (accessed on 25 March 2020).

76. Abbasov, F. EU Shipping's Climate Record. Available online: https://www.transportenvironment.org/sites/te/ files/publications/Study-EU_shippings_climate_record_20191209_final.pdf (accessed on 25 March 2020).

77. Hoffmann, J. Decarbonizing Maritime Transport: Estimating Fleet Renewal Trends Based on Ship Scrapping Patterns; UNCTAD: Geneva, Switzerland, 2020. Available online: https://unctad.org/en/pages/newsdetails.aspx? OriginalVersionID=2288 (accessed on 1 May 2020).

78. Hoffman, J.; Rydbergh, T.; Stevenson, A. Decarbonizing Shipping: What Role for Flag States? UNCTAD: Geneva, Switzerland, 2020. Available online: https://unctad.org/en/pages/newsdetails.aspx?OriginalVersionID=2309 (accessed on 1 May 2020).

(C) 2020 by the authors. Licensee MDPI, Basel, Switzerland. This article is an open access article distributed under the terms and conditions of the Creative Commons Attribution (CC BY) license (http://creativecommons.org/licenses/by/4.0/). 